\title{
Improved Oil Recovery in Fluvial Dominated Deltaic Reservoirs of Kansas - Near-Term
}

\author{
Quarterly Report \\ July 1 - September 30, 1997
}

\author{
By: \\ D. W. Green; G. P. Willhite; A. Walton; D. McCune \\ R. Reynolds; M. Michnick; L. Watney
}

\author{
Work Performed Under Contract No.: DE-FC22-93BC14957 \\ For \\ U.S. Department of Energy \\ Office of Fossil Energy \\ Federal Energy Technology Center \\ P.O. Box 880 \\ Morgantown, West Virginia 26507-0880
}

By

The University of Kansas Center for Research, Inc.

Lawrence, Kansas 66045 


\section{Disclaimer}

This report was prepared as an account of work sponsored by an agency of the United States Government. Neither the United States Government nor any agency thereof, nor any of their employees, makes any warranty, express or implied, or assumes any legal liability or responsibility for the accuracy, completeness, or usefulness of any information, apparatus, product, or process disclosed, or represents that its use would not infringe privately owned rights. Reference herein to any specific commercial product, process, or service by trade

name, trademark, manufacturer, or otherwise does not necessarily constitute or imply its endorsement, recommendation, or favoring by the United States Government or any agency thereof. The views and opinions of authors expressed herein do not necessarily state or reflect those of the United States Government or any agency thereof. 
Cooperative A greement N umber DE-FC22-93BC14957--18

The University of Kansas Center for Research, Inc.

October 15, 1997

Budget Period \#1 Duration from (6/18/93 - 03/31/95

Budget Period \#2 Duration from 04/01/95 - 12/31/98

DOE A ward \$2,007,446

\author{
Program M anager \\ D on W. Green \\ University of $K$ ansas \\ L awrence, Kansas \\ Principal Investigators \\ D on W. Green \\ G. Paul Willhite
}

Co-Investigators

A. Walton, D. M cC une, R. Reynolds, M. M ichnick, L.W atney

DOE Project Officer

$R$ honda P. L indsey

Bartlesville Project Office

Reporting Period 07/01/97 - 09/30/97

(17th Quarterly Report)

"U.S./DOE PATENT CLEARANCES NOT REQUIRED
PRIOR TO PUBLICATIONO F THIS DOCUMENT" 


\section{O bjectives}

The objective of this project is to address waterflood problems of the type found in M orrow sandstone reservoirs in southwestern $\mathrm{K}$ ansas and in Cherokee Group reservoirs in southeastern $\mathrm{K}$ ansas. Two demonstration sites operated by different independent oil operators are involved in this project. The Stewart Field is located in Finney County, Kansas and is operated by N orth A merican Resources Company. The N elson Lease is located in A llen County, Kansas, in the N.E. Savonburg Field and is operated by James E. Russell Petroleum, Inc.

General topics to be addressed are 1) reservoir management and performance evaluation, 2) waterflood optimization, and 3) the demonstration of recovery processes involving off-the-shelf technologies which can be used to enhance waterflood recovery, increase reserves, and reduce the abandonment rate of these reservoir types.

In the Stewart Project, the reservoir management portion of the project conducted during Budget Period 1 involved performance evaluation. This included 1) reservoir characterization and the development of a reservoir database, 2) volumetric analysis to evaluate production performance, 3) reservoir modeling, 4) laboratory work, 5) identification of operational problems, 6) identification of unrecovered mobile oil and estimation of recovery factors, and 7) identification of the most efficient and economical recovery process.

To accomplish these objectives the initial budget period was subdivided into three major tasks. The tasks were 1) geological and engineering analysis, 2) laboratory testing, and 3) unitization. Due to the presence of different operators within the field, it was necessary to unitize the field in order to demonstrate a field-wide improved recovery process. This work was completed and the project moved into Budget Period 2.

Budget Period 2 objectives consisted of the design, construction, and operation of a field-wide waterflood utilizing state-of-the-art, off-the-shelf technologies in an attempt to optimize secondary oil recovery. To accomplish these objectives the second budget period was subdivided into five major tasks. The tasks were 1) design and construction of a waterflood plant, 2) design and construction of a water injection system, 3) design and construction of tank battery consolidation and gathering system, 4) initiation of waterflood operations and reservoir management, and 5) technology transfer. Tasks 1-3 have been completed and water injection began in October 1995.

In the Savonburg Project, the reservoir management portion involves performance evaluation. This work included 1) reservoir characterization and the development of a reservoir database, 2) identification of operational problems, 3) identification of near wellbore problems such as plugging caused from poor water quality, 4) identification of unrecovered mobile oil and estimation of recovery factors, and 5) preliminary identification of the most efficient and economical recovery process i.e., polymer augmented waterflooding or infill drilling (vertical or horizontal wells).

To accomplish this work the initial budget period was subdivided into four major tasks. The tasks included 1) geological and engineering analysis, 2) waterplant optimization, 3) wellbore cleanup and pattern changes, and 4) field operations. This work was completed and the project has moved into Budget Period 2.

The Budget Period 2 objectives consisted of continual optimization of this mature waterflood in an attempt to optimize secondary and tertiary oil recovery. To accomplish these objectives the second budget period is subdivided into six major tasks. The tasks were 1) waterplant development, 2) profile modification treatments, 3) pattern changes, new wells and wellbore cleanups, 4) reservoir development (polymer flooding), 5) field operations, and 6) technology transfer. 


\section{Summary of Technical Progress}

\section{Stewart Field Project}

\section{T ask II.1 - Design/C onstruct W aterflood Plant}

Summary of work in last quarter

No major work.

Summary of planned work for next quarter

N one planned at this time, but adaptations will be made as necessary.

\section{Task II.2 - Design/C onstruct Injection System}

Summary of work in last quarter

No major work.

Summary of planned work for next quarter

No additional construction work planned at this time.

\section{Task II.3 - Design/C onstruct Battery C onsolidation and G athering System}

Summary of work in last quarter

No major work.

Summary of planned work for next quarter

M ake adaptations as needed for an efficient cost effective operation.

\section{Task II.4 - Waterflood O perations and Reservoir Management}

Summary of work in last quarter

Installed a 640 pumping unit and 2-inch insert pump on the Bulger 7-4 to replace the 320 unit and the 1.75-inch pump. Installed a 320 pumping unit on the M eyer 10-1 and also lowered the tubing and installed a 1.75-inch pump. The 320 unit replaced a 114 unit on the M eyer 10-1. These two artificial lift upgrades were performed as a result of rising fluid levels.

Ongoing pump changes, installation of tubing anchors, stroke length changes and speeding up pumping units were performed during the quarter on several wells. These changes are made as a result of the well testing program that identifies wells with production problems, rising fluid levels, abnormal 
production trends and low pump efficiencies. The changes that were made are a continued effort to maximize oil production and keep all the wells near a pumped off condition.

Continued to monitor production and injection rates, water supply volumes, and injection pressures. Continued the ongoing testing of producing wells with test trailers and fluid level instruments. A general increase in the water/oil ratio in a few of the better producers occurred during the quarter and has resulted in a slight decrease in the total field oil production. Ongoing allocation of the injection volumes in the injection wells were performed based on response in producers and injectors, but overall field injection rates have remained constant at 5700 BW PD. Daily production and injection rates for the field are displayed on the attached plot.

N orth A merican R esources Company entered into a sales agreement on the Stewart Field waterflood with PetroSantander, Inc. of Houston, TX in September. The sale is scheduled to be finalized October 10, 1997 and PetroSantander will take over operations of the Stewart waterflood on October 11, 1997.

Summary of planned work for next quarter

Continue to monitor for response at producing wells with well tests and fluid levels. Update the reservoir computer model and simulate when applicable. M onitor water treatment program. U pgrade pumping equipment as necessary.

\section{Task II.5 - Technology Transfer}

Summary of work in last quarter

Continued to publicize information on the Stewart Field's increased oil production. Presentations on the Stewart Field were presented on A ugust $25^{\text {th }}$ at the annual meeting of the $K$ ansas Independent Oil and Gas A ssociation in W ichita, Kansas and September $11^{\text {th }}$ at the K iwanis meeting in L awrence, Kansas.

Operators throughout the region continue to visit the field to view the state-of-the-art waterflood installation and computerized monitoring system.

Summary of planned work for next quarter

Continue to publicize information on the Stewart Field's increased oil production. A presentation is scheduled at a symposium sponsored by the U niversity of Wyoming Enhanced Oil Recovery Institute for October 29-30 in Casper, WY . 


\section{Summary of Technical Progress}

\section{Savonburg Field Project}

\section{Task II.1 - Water Plant Development}

Summary of work in last quarter

In order to improve the quality of the injection water, the following changes were made in July:

1) A different chemical pump was installed for the polymer feed.

2) A nother chemical pump was placed in service for adding bleach to the system.

3) An Ecosol meter was re-installed in the water transfer line.

4) The air flotation unit discharge tank was thoroughly cleaned, jetted and treated with bleach.

During July, the plant was operated at a reduced pressure and volume due to the lack of available water. Poor water quality and filter plugging caused this shortfall.

The water injection system received a thorough cleaning during A ugust. All tanks and lines were flushed and cleaned and filters changed.

Summary of planned work for next quarter

The water plant will be continually monitored and optimized as problems arise.

\section{Task II.2 - Profile M odification T reatments}

Summary of work in last quarter

A channel-block treatment was performed on well H-14.

Summary of work planned for next quarter

At quarter's end efforts are being made to prepare well RW-8 for a gel-polymer treatment. As time allows, more wells will be treated during the next quarter.

\section{Task II.3 - Pattern C hanges and W ellbore C leanup}

Summary of work in last quarter

W ell 0-1 was reperforated in the B-3 zone and tubing and a packer were installed in $\mathrm{H}-13$ in July. Several wells received surface repairs to equipment in A ugust.

A channel-block treatment was performed on well $\mathrm{H}-14$. 
W ells KW -7, KW-11, RW -2 and RW -6 were acidized through coiled tubing in September.

The following wells were serviced during the second quarter: $\mathrm{H}-20, \mathrm{H}-22$ and $\mathrm{H}-30$ (three times). The service was required to replace joints of 1 " pumping string that developed leaks, and to service pumps.

Summary of planned work for next quarter

W ells will be tested, cleaned and worked on as needed.

\section{Task II.4 - Reservoir Development (Polymer Flooding)}

Summary of work in last quarter

Waiting on a decision to implement polymer flooding.

Summary of work for next quarter

Waiting on a decision to implement polymer flooding.

\section{Task II.5 - Field O perations}

Summary of work in last quarter

Normal field operations have included: 1) monitoring wells on a daily basis, 2) repairing waterplant, piping, and wells as required, 3) collecting daily rate and pressure data, and 4) solving any other daily field operational problem that might occur.

\begin{tabular}{|c|c|}
\hline Month & Oil Proo \\
\hline October 1993 & $26.4 \mathrm{~B} / \mathrm{D}$ \\
\hline November 1993 & $30.7 \mathrm{~B} / \mathrm{D}$ \\
\hline December 1993 & $32.0 \mathrm{~B} / \mathrm{D}$ \\
\hline January 1994 & $30.8 \mathrm{~B} / \mathrm{C}$ \\
\hline February 1994 & $30.9 \mathrm{~B} / \mathrm{C}$ \\
\hline M arch 1994 & $30.3 \mathrm{~B} / \mathrm{C}$ \\
\hline April 1994 & $29.1 \mathrm{~B} / \mathrm{C}$ \\
\hline M ay 1994 & $28.5 \mathrm{~B} / \mathrm{C}$ \\
\hline June 1994 & $30.3 \mathrm{~B} / \mathrm{C}$ \\
\hline July 1994 & $28.9 \mathrm{~B} / \mathrm{L}$ \\
\hline A ugust 1994 & $24.6 \mathrm{~B} / \mathrm{C}$ \\
\hline October 1994 & $23.0 \mathrm{~B} / \mathrm{C}$ \\
\hline November 1994 & $25.7 \mathrm{~B} / \mathrm{L}$ \\
\hline December 1994 & $27.8 \mathrm{~B} / \mathrm{C}$ \\
\hline January 1995 & $27.0 \mathrm{~B} / \mathrm{L}$ \\
\hline February 1995 & $25.3 \mathrm{~B} / \mathrm{C}$ \\
\hline M arch 1995 & $22.4 \mathrm{~B} / \mathrm{L}$ \\
\hline A pril 1995 & $22.4 \mathrm{~B} / \mathrm{L}$ \\
\hline
\end{tabular}




$\begin{array}{ll}\text { May } 1995 & 25.0 \mathrm{~B} / \mathrm{D} \\ \text { June } 1995 & 23.9 \mathrm{~B} / \mathrm{D} \\ \text { July } 1995 & 26.8 \mathrm{~B} / \mathrm{D} \\ \text { A ugust } 1995 & 25.2 \mathrm{~B} / \mathrm{D} \\ \text { September } 1995 & 24.8 \mathrm{~B} / \mathrm{D} \\ \text { October } 1995 & 24.4 \mathrm{~B} / \mathrm{D} \\ \text { N ovember } 1995 & 24.4 \mathrm{~B} / \mathrm{D} \\ \text { December } 1995 & 26.3 \mathrm{~B} / \mathrm{D} \\ \text { January } 1996 & 28.0 \mathrm{~B} / \mathrm{D} \\ \text { February } 1996 & 29.2 \mathrm{~B} / \mathrm{D} \\ \text { March } 1996 & 27.2 \mathrm{~B} / \mathrm{D} \\ \text { A pril } 1996 & 26.7 \mathrm{~B} / \mathrm{D} \\ \text { May } 1996 & 26.6 \mathrm{~B} / \mathrm{D} \\ \text { June } 1996 & 24.9 \mathrm{~B} / \mathrm{D} \\ \text { July } 1996 & 25.4 \mathrm{~B} / \mathrm{D} \\ \text { A ugust } 1996 & 26.5 \mathrm{~B} / \mathrm{D} \\ \text { September } 1996 & 26.1 \mathrm{~B} / \mathrm{D} \\ \text { October } 1996 & 27.1 \mathrm{~B} / \mathrm{D} \\ \text { N ovember } 1996 & 26.4 \mathrm{~B} / \mathrm{D} \\ \text { December } 1996 & 27.8 \mathrm{~B} / \mathrm{D} \\ \text { January } 1997 & 26.9 \mathrm{~B} / \mathrm{D} \\ \text { February } 1997 & 26.9 \mathrm{~B} / \mathrm{D} \\ \text { March } 1997 & 27.5 \mathrm{~B} / \mathrm{D} \\ \text { A pril } 1997 & 26.3 \mathrm{~B} / \mathrm{D} \\ \text { May } 1997 & 25.5 \mathrm{~B} / \mathrm{D} \\ \text { June } 1997 & 24.6 \mathrm{~B} / \mathrm{D} \\ \text { July } 1997 & 23.5 \mathrm{~B} / \mathrm{D} \\ \text { A ugust } 1997 & 24.3 \mathrm{~B} / \mathrm{D} \\ \text { September } 1997 & 23.8 \mathrm{~B} / \mathrm{D}\end{array}$

Summary of planned work for next quarter

Field operations will be continued.

\section{Task II.6 - Technology Transfer}

Summary of work in last quarter

A plant tour was conducted for M ike M adden of BDM/Oklahoma in June.

Summary of planned work for next quarter

The field will be visited by other operators from the area. 


\section{Stewart Waterflood Daily Totals}

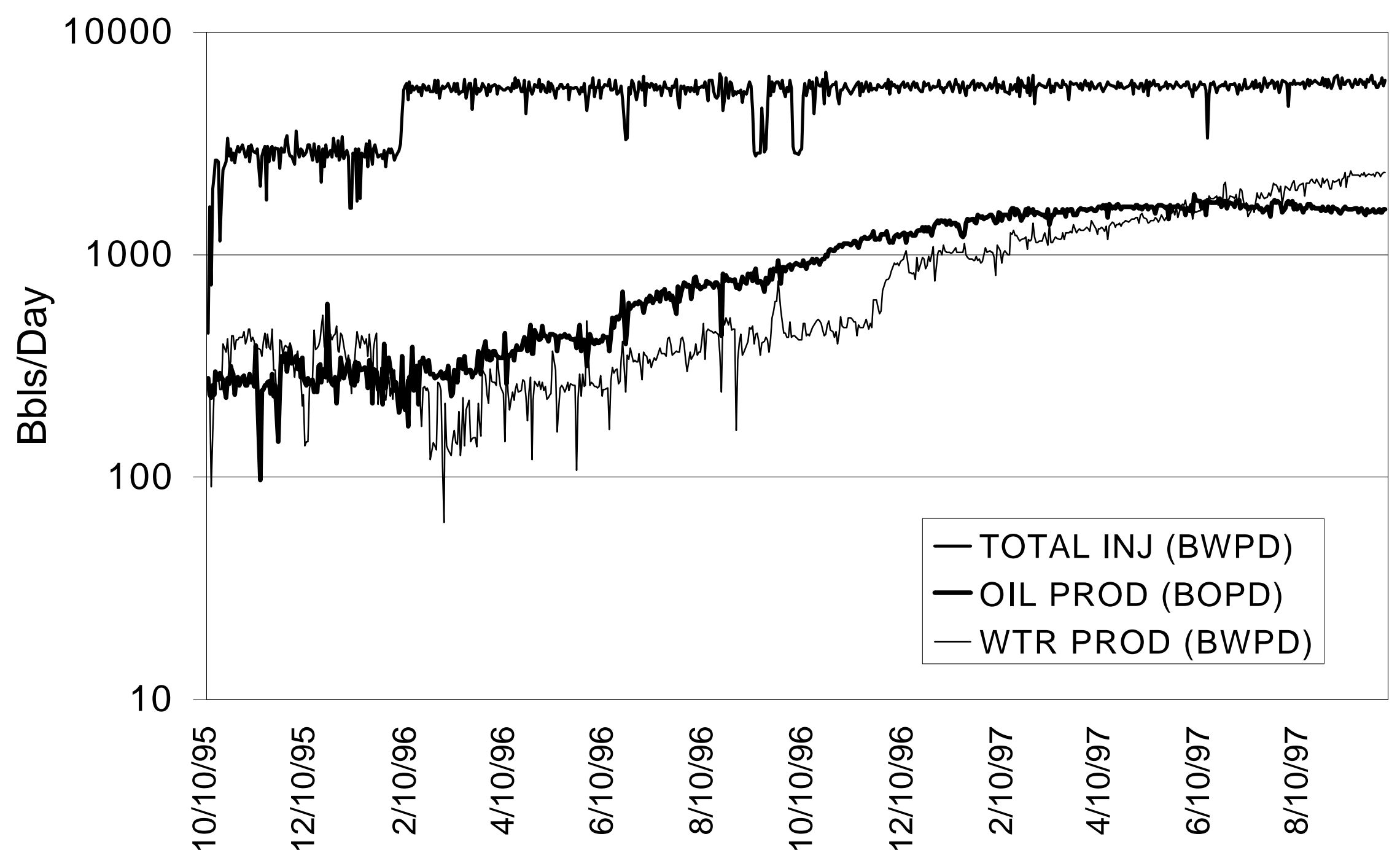

